\title{
In situ preservation of "Pholas tzayi Hu, 1992" (Mollusca, Pholadidae) from Chinshui Shale (Pliocene) in western Taiwan
}

\author{
Yen-Ju Lin ${ }^{1,2}, \mathrm{Jia}-\mathrm{Yu} \mathrm{Lin}^{2}$, and Leh-Chyun $\mathrm{Wu}^{3, *}$ \\ ${ }^{I}$ Department of Science Education, National Taipei University of Education, Taipei City, Taiwan \\ ${ }^{2}$ Department of Geosciences, National Taiwan University, Taipei City, Taiwan \\ ${ }^{3}$ Department of Geology, Chinese Culture University, Taipei City, Taiwan
}

\begin{abstract}
Article history:
Received 30 August 2021

Revised 10 December 2021

Accepted 15 December 2021

Keywords:

Stratigraphic facing, Plio-Pleistocene boundary, Bioturbation, Black shale

\section{Citation:}

Lin, Y.-J., J.-Y. Lin, and L.-C. $\mathrm{Wu}, 2021$ : In situ preservation of "Pholas tzayi Hu, 1992" (Mollusca, Pholadidae) from Chinshui Shale (Pliocene) in western Taiwan. Terr. Atmos. Ocean. Sci., 32, 1131-1140, doi: 10.3319/TAO.2021.12.15.01
\end{abstract}

\begin{abstract}
A total of 30 specimens of "Pholas tzayi Hu, 1992" were collected from the Chinshui Shale (Upper Pliocene) at the Laotinliao Creek, Touwu Township, Miaoli County, Taiwan. Among them, 18 specimens are preserved with both valves and 8 specimens are preserved with diagnostic characters. Field observation shows that many specimens are preserved with unbroken valves and buried with the posterior end pointing upward and perpendicular to the bedding; thus, stratigraphic facing can be inferred based on pholadid bivalves buried in situ. This is important because Chinshui Shale consists of intensely bioturbated, muddy sandstone and organic-rich mudstone without obvious bedding surfaces. The layer of intact pholadid bivalves not only provides clues about original seafloor conditions but also contains information about original bedding orientation. Furthermore, this layer has been noted in more than one locality and can be used as a key layer for correlation. Rapid sedimentation events, such as obrution, can contribute to the death of organisms. Organisms found in obrution deposits tend to have a better chance to get preserved in the fossil records because that rapid burial implies anoxic or dysoxic conditions within the sediment layers preventing further bioerosion due to scavenging activities. This study helps us to understand the invertebrate faunal evolution near the Plio-Pleistocene boundary in Taiwan. Due to the short range of occurrence of this endemic species " $P$. tzayi" which has been reported from several localities, it is recognized as one of the key fossils for Chinshui Shale.
\end{abstract}

\section{INTRODUCTION}

The Chinshui Shale is one of the petroleum target units in NW Taiwan (Pan 2015). Recent studies of Chinshui Shale focused on its structural setting (Chiu 2009, 2018; Pan 2011; Yeh 2017) and its foraminifer biostratigraphy (Pan 2011, 2015). In comparison, the macrofauna received very little attention. Important studies on fossil mollusks from Taiwan took place in the second half of $20^{\text {th }}$ century (Lin 1974, 1975, 1976; Chang and Lin 1978; Lin and Liew 1978; Kanno et al. 1985; Masuda 1990; Masuda and Huang 1994) and during the Japanese colonial rule (1910 - 1945) (Deguchi 1912; Yokoyama 1920, 1928; Hayasaka 1931, 1939; Tan 1932, 1933, 1937; Nomura 1933, 1935, 1938; Hayasaka and Lin 1934; Hayasaka and Tan 1934a, b, 1935; Otuka 1936; Kuroda 1939, 1940; Kaneko 1943). Many type series of certain taxa, figured specimens, and literature sources were lost during the Second World War. Because the Chinshui Shale is deposited relatively close to the Plio-Pleistocene boundary, this contribution helps us to understand the invertebrate faunal evolution across the boundary. We focused on the well-preserved "P.tzayi" and its implications for understanding the faunal succession and environmental settings of Chinshui Shale. The goals of this study are: (1) to investigate the living conditions of fossil assemblage from Chinshui Shale; (2) to speculate about its possible cause of death; and (3) to infer whether the studied assemblage is allochthonous or autochthonous.

\footnotetext{
* Corresponding author

E-mail:wulehch@ulive.pccu.edu.tw
} 


\section{MATERIAL AND METHODS}

\subsection{Geologic Settings}

The studied area is exposed along the Laotianliao Creek in the Touwu Township, Miaoli County. It is located approximately $1 \mathrm{~km}$ west of Mingde Dam (Fig. 1). Exposure is on the Laotianliao Creek bed in the downstream direction of Mingde Dam. The studied section of the Chinshui Shale is located on the axis of Chinshui Anticline. The thickness of the unit cropping out varies from 4 to $70 \mathrm{~m}$.

Studied section is approximately $6 \mathrm{~m}$ thick, dominated by intensely bioturbated muddy sandstones with rare sedimentary structures (Fig. 2a). The section is composed of three parts (Fig. 2b). The lower part is approximately $2 \mathrm{~m}$ thick and is dominated by fine-grained sandstone with hummocky cross-stratification (HCS), intense bioturbation, and rare fossil shells. The middle part is approximately 1.8 to $2 \mathrm{~m}$ thick and is dominated by bioclasts and foraminifers which are filled in burrows. The size of burrows is larger than the one in the lower part and some sedimentary structures (e.g., HCS) are present. The upper part is 2 to $2.2 \mathrm{~m}$ thick and contains well-preserved fossils and transported bioclasts, and bioturbation is low compared to other parts. Fossils are dominated by pholadid bivalve "P. tzayi" and they tend to be concentrated within one layer with one preferred orientation (Fig. 2c). There are some burrows above the bivalve layer made either by bivalves or by arthropods. The boundary between Chinshui and the overlying Cholan Formation is approximately $20 \mathrm{~m}$ above the section based on the regional geologic map. Thus, the studied section represents the upper portion of Chinshui Shale.

\subsection{Fossils}

A total of 30 specimens of "Pholas tzayi Hu, 1992", including incomplete valves, were collected from the unit. At least 18 of them have complete outlines suitable for length and width measurements. Eight specimens are preserved in very good conditions. Valves are unbroken and shell fragments are easily separated from molds and crumble when touched. The body cavity is filled with mud and no internal structures can be observed without further preparation. Terminology in Cox et al. (1969), Kennedy (1974), and Carter et al. (2012) are adopted here, and fossil orientations follow Hryniewicz and Gaździcki (2016). Illustrated specimens are deposited at the National Museum of Natural Science, Taichung (NMNS) and the Department of Geosciences, National Taiwan University, Taipei (NTUG).

\section{SYSTEMATICS}

Family Pholadidae Lamarck, 1809

Subfamily Pholadinae Lamarck, 1809

Genus Pholas Linné, 1758
"Pholas tzayi $\mathrm{Hu}, 1992 "$

Description: Based on newly collected specimens, shells are streamline, anterior is larger than posterior, shell thin. Umbo is located on the anterior end and is projected outward. Valves biconvex with the maximum width along the umbo, decreasing width sharply anteriorly and decreasing width gradually posteriorly. Anterior margin indented, posterior margin straight or slightly convex. Ventral margin straight, curved at both ends, cymbiform. Valves contain growth lines with uneven thickness, thicker growth lines toward apex.

Locality and stratum: Laotinliao Creek, Touwu Township, Miaoli County; Chinshui Shale.

Remarks: Several fossil species of Pholadidae have been reported from Taiwan (Lin and Liew 1978; Wang 1983, 1984) (Table 1), studied bivalves are identified as "Pholas tzayi $\mathrm{Hu}, 1992$ ". Hu (1992) described it in a monograph and it was named after Professor Dong-Jiang Tzay who collected the specimens. However, pholadid bivalves were not reported from the Zhudong section of the same unit reported in Hu (1993). Masuda and Huang (1994) reported two species Barnea (Anchomosa) manilensis (Philippi, 1847) and Barnea (Umitakea) dilatata (Souleyet, 1843) from the Chinshui Shale of Houlong section, Miaoli. Subsequently, Hu (1995) illustrated a drawing of Barnea (Umitakea) japonica (Yokoyama) from Chinshui Shale without detailed description and locality information. A detailed systematic study of fossil specimens from Taiwan is a subject of a separate publication. For this study collected specimens are referred to as "P.tzayi Hu, 1992".

Holotype specimen (NMNS 006222) in $\mathrm{Hu}$ (1992) is $2.8 \mathrm{~cm}$ tall, $6.4 \mathrm{~cm}$ long, and $3.0 \mathrm{~cm}$ wide for both valves (Fig. 3). The representative specimen in our collection is 2.3 $\mathrm{cm}$ tall, $5.3 \mathrm{~cm}$ long, and $2.4 \mathrm{~cm}$ wide (Fig. 4). In addition, mesoplax is well-preserved in our specimens (Figs. 4 - 8).

\section{DISCUSSION}

\subsection{Ichnofacies}

Abundant trace fossils are observed in the outcrop (Fig. 9). Although a more detailed investigation is needed in order to understand fully the trace fossil ichno-assemblage in the studied area, they are common members in Scolicia ichnofacies, which represents a neritic zone in middle offshore settings below the fair-weather wave base and above storm wave base (5 to $15 \mathrm{~m}$ of water depth). This is in agreement with the ichnofacies reported for the Chinshui Shale in Chen (1994).

\subsection{Taphonomy}

The influence of rapid burial on infaunal bivalve taphonomy has been recently discussed by Hryniewicz et al. (2020). Pholadids similar to the ones described here 


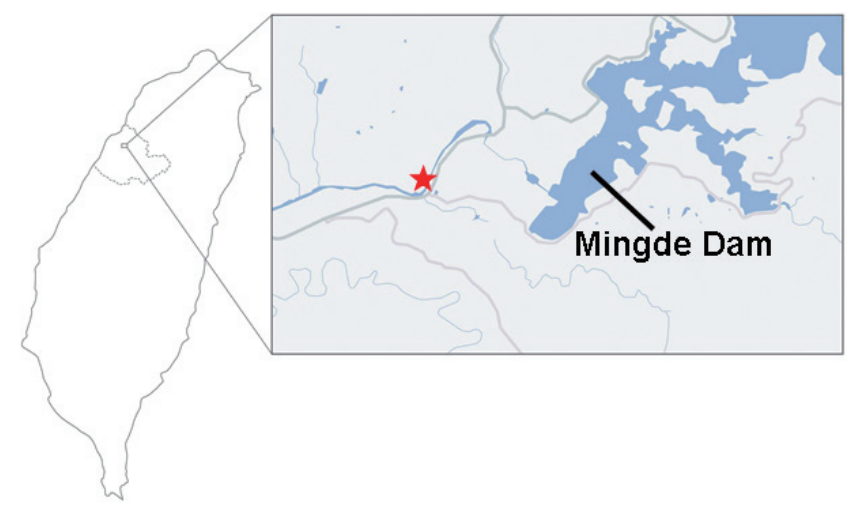

Fig. 1. Map of mainland Taiwan with the enlarged area of Mingde Dam. Star indicated the fossil location.

(a)

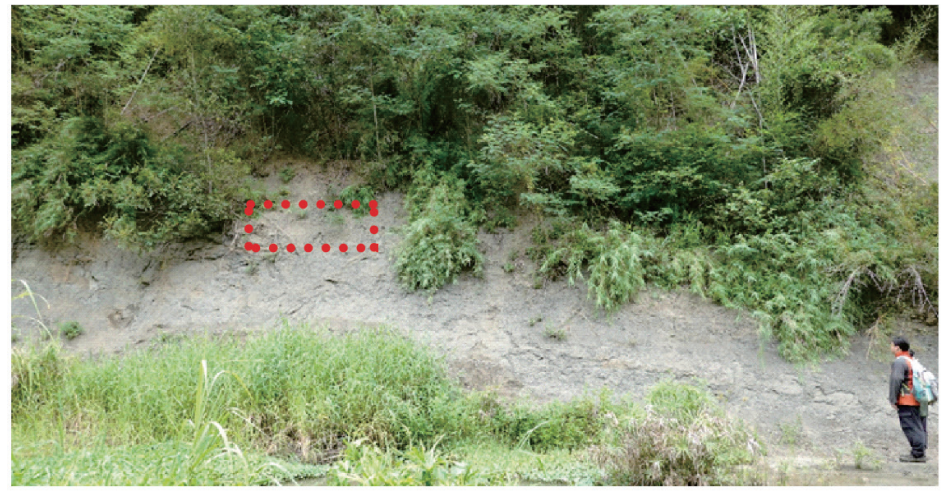

(b)

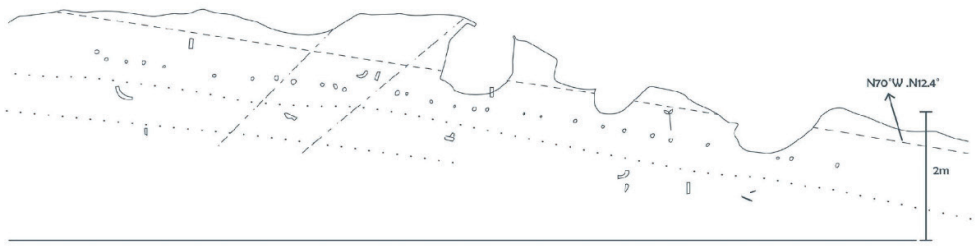

(c)

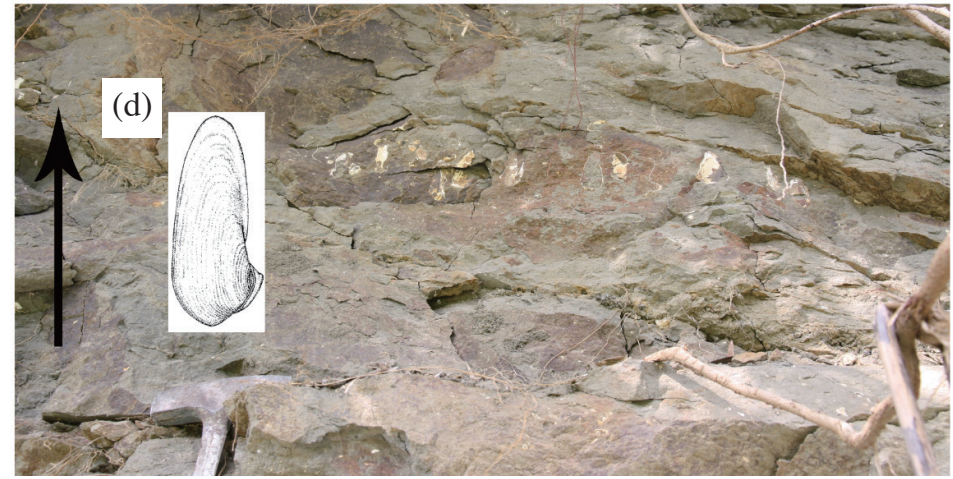

Fig. 2. Outcrop photos (a) (c) and the interpreted drawings (b) (d). (a) Outcrop photo of Chinshui Shale. (b) Outcrop drawing. (c) Fossil bivalves in the field with the arrow pointing toward the stratigraphic up; approximate outcrop photo was taken from the dotted area in (a). (d) Interpretive drawing of a fossil bivalve in preserved orientation, noting the anterior end is pointing stratigraphic up. 
Table 1. List of reported fossil pholadid bivalves from Taiwan.

\begin{tabular}{cc}
\hline Taxon & Reference \\
\hline Barnea cf. manilensis & Lin and Liew 1978 \\
Barnea latissima & Lin and Liew 1978 \\
Barnea sp. & Lin and Liew 1978 \\
Barnea (Anchomosa) manilensis & Masuda and Huang 1994 \\
Barnea (Umitakea) dilatata & Masuda and Huang 1994 \\
Barnea (Umitakea) japonica & Hu 1995 \\
Barnea (Taiwanobarnea) shihchoensis & Wang 1983 \\
Jouannetia (s. s.) cumingii & Lin and Liew 1978 \\
Pholadomya sp. & Lin and Liew 1978 \\
Pholadomya turunagai & Lin and Liew 1978 \\
Pholadomya (Bucardiomya) sp. & Wang 1984 \\
Pholas sp. & Lin and Liew 1978 \\
Pholas tzayi & Hu 1992 \\
\hline
\end{tabular}

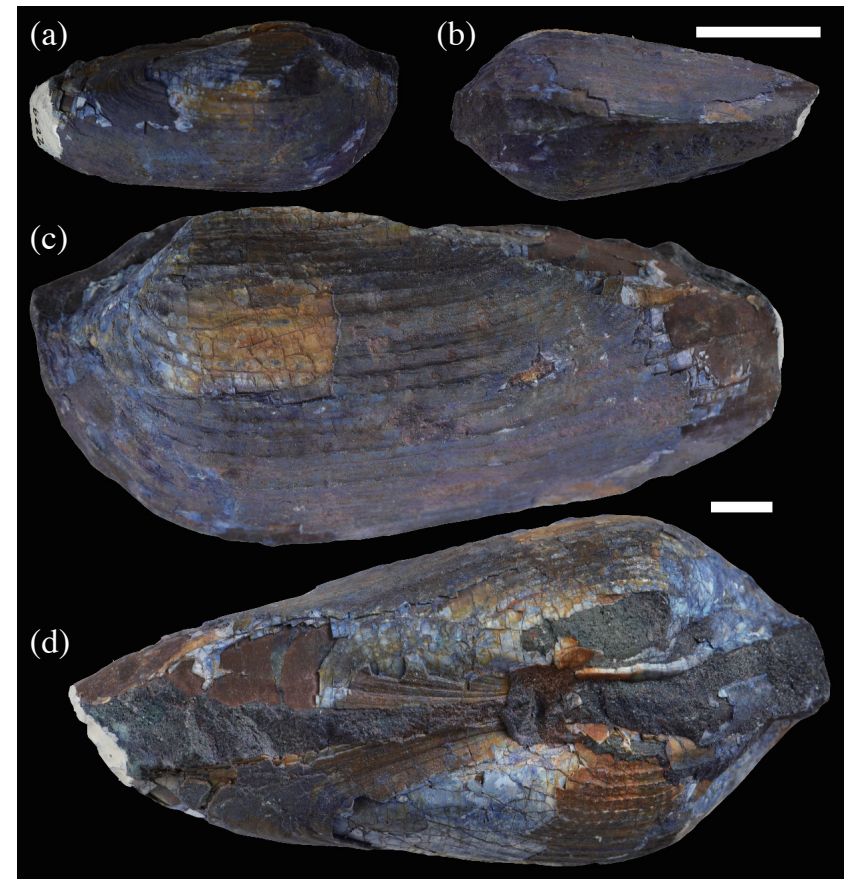

Fig. 3. Holotype (NMNS 006222) of Pholas tzayi Hu, 1992. Scales $=2 \mathrm{~cm}$ (a) - (d). (a) Right lateral view. (b) Ventral view. (c) Left lateral view. (d) Dorsal view. 

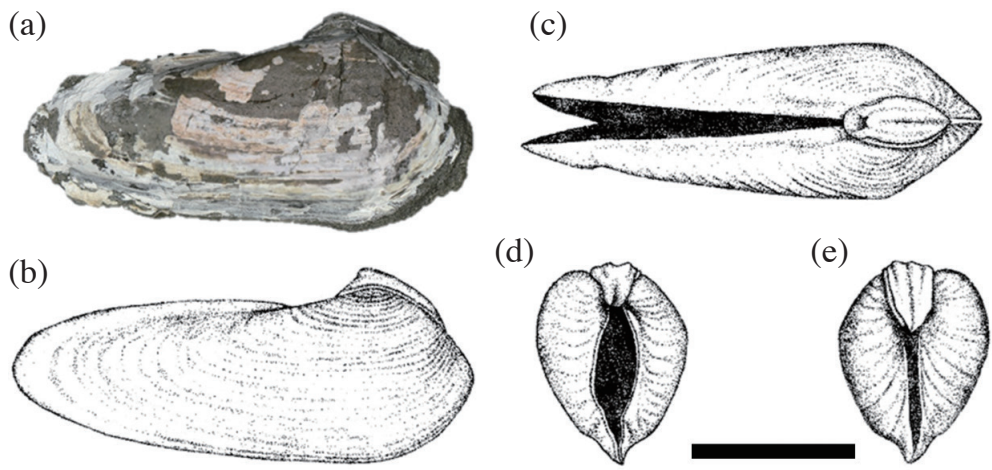

(d)

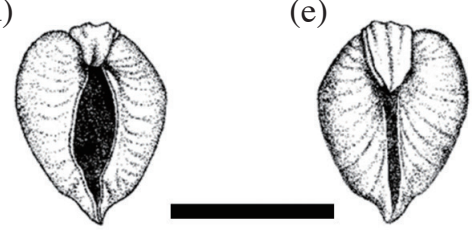

Fig. 4. New specimen (NTUG300-FN00101) of "P. tzayi Hu, 1992" with interpreted drawings (b) - (e). Scales = 2 cm (a) - (e). (a) Photo of right valve, anterior end is to the right. (b) Drawing of the right valve, anterior end is to the right. (c) Drawing in dorsal view. (d) Drawing in posterior view. (e) Drawing in anterior view.

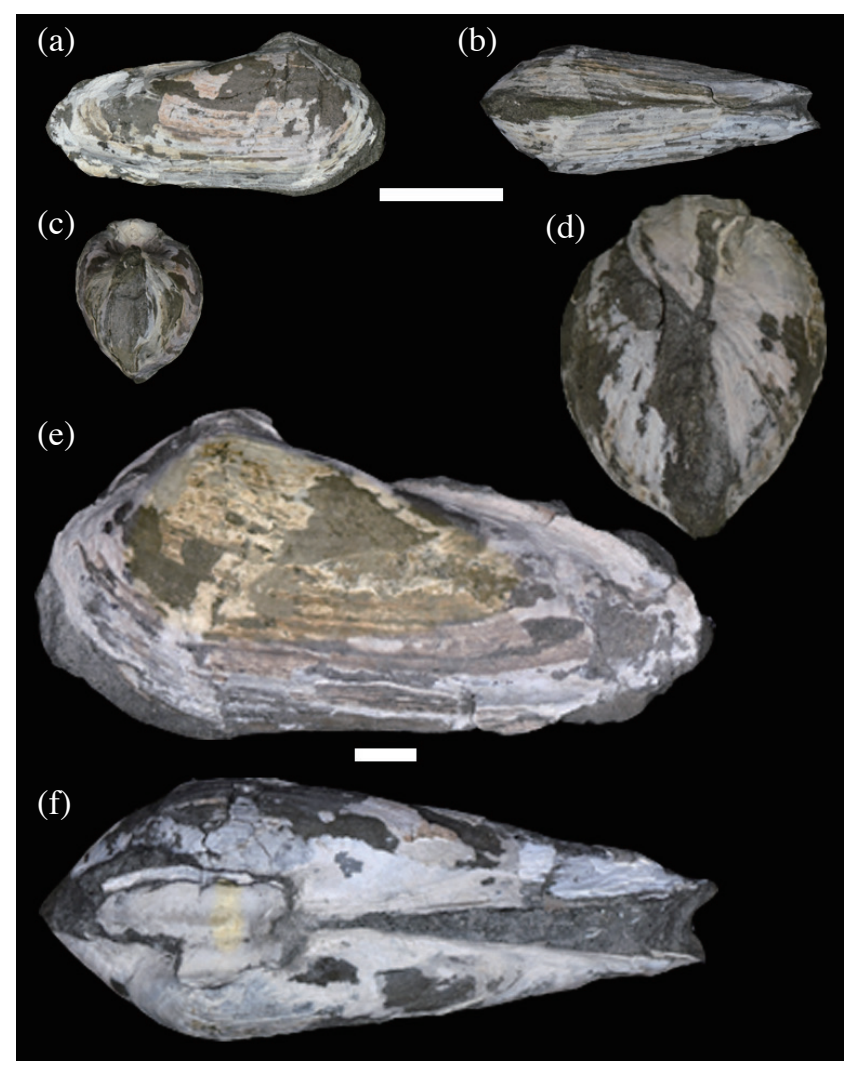

Fig. 5. Specimen (NTUG300-FN00101) of "P. tzayi Hu, 1992”. Scales $=2 \mathrm{~cm}$ (a) - (f). (a) Right lateral view. (b) Ventral view. (c) Posterior view. (d) Anterior view. (e) Left lateral view. (f) Dorsal view.

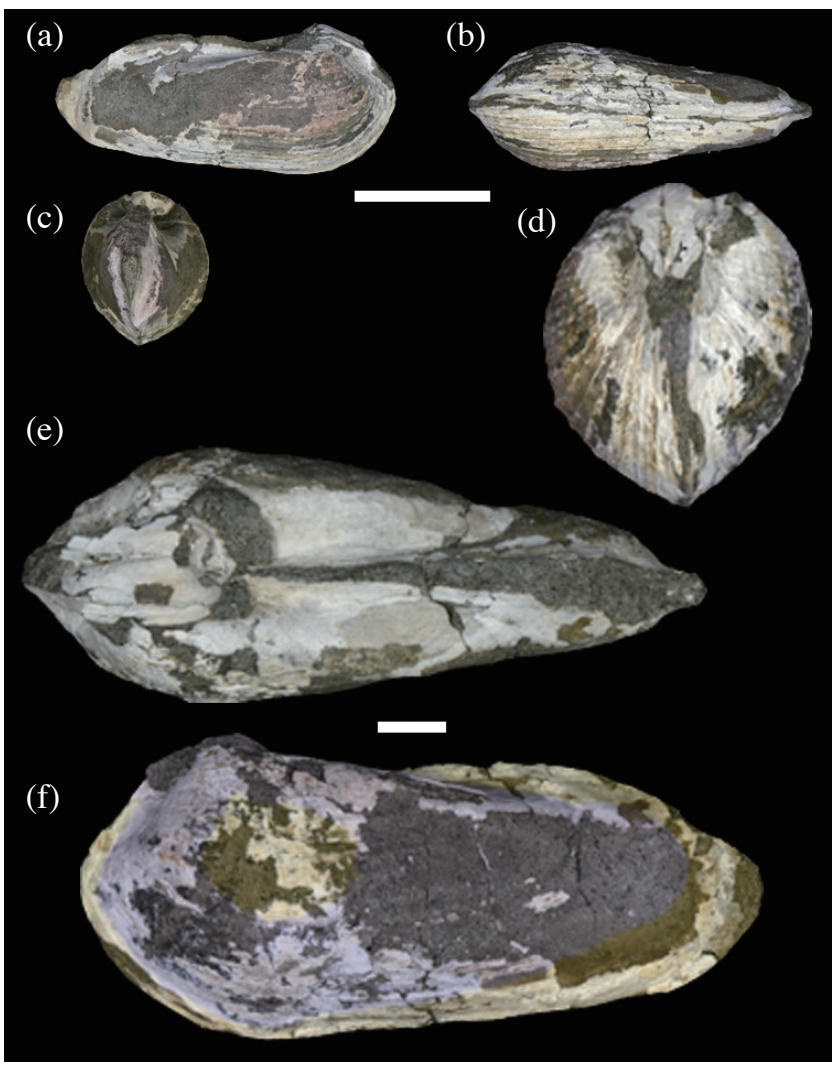

Fig. 6. Specimen (NTUG300-FN00102) of “P. tzayi Hu, 1992”. Scales $=2 \mathrm{~cm}$ (a) - (f). (a) Right lateral view. (b) Ventral view. (c) Posterior view. (d) Anterior view. (e) Dorsal view. (f) Left lateral view. 


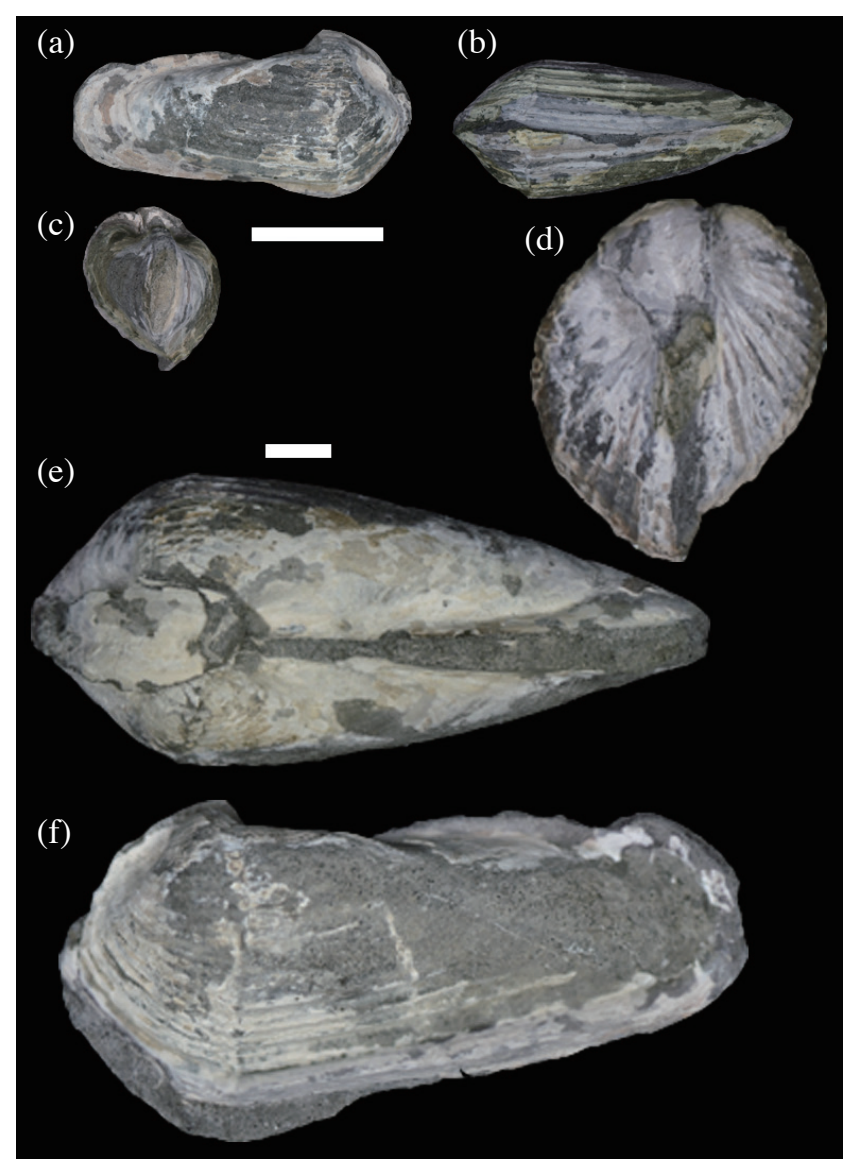

Fig. 7. Specimen (NTUG300-FN00103) of "P. tzayi Hu, 1992". Scales $=2 \mathrm{~cm}$ (a) - (f). (a) Right lateral view. (b) Ventral view. (c) Posterior view. (d) Anterior view. (e) Dorsal view. (f) Left lateral view.

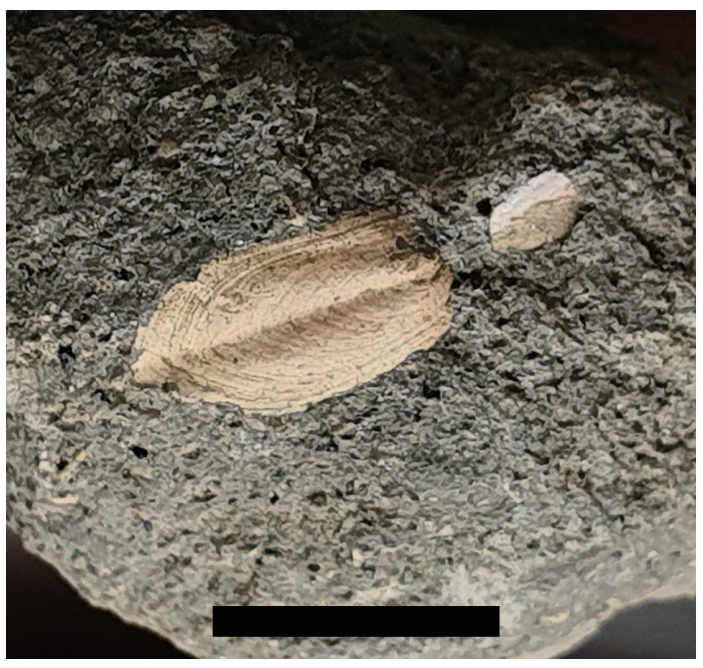

Fig. 8. Isolated accesorial plate for a fossil pholadid bivalve found in the same outcrop. Scale bar $=5 \mathrm{~mm}$. 

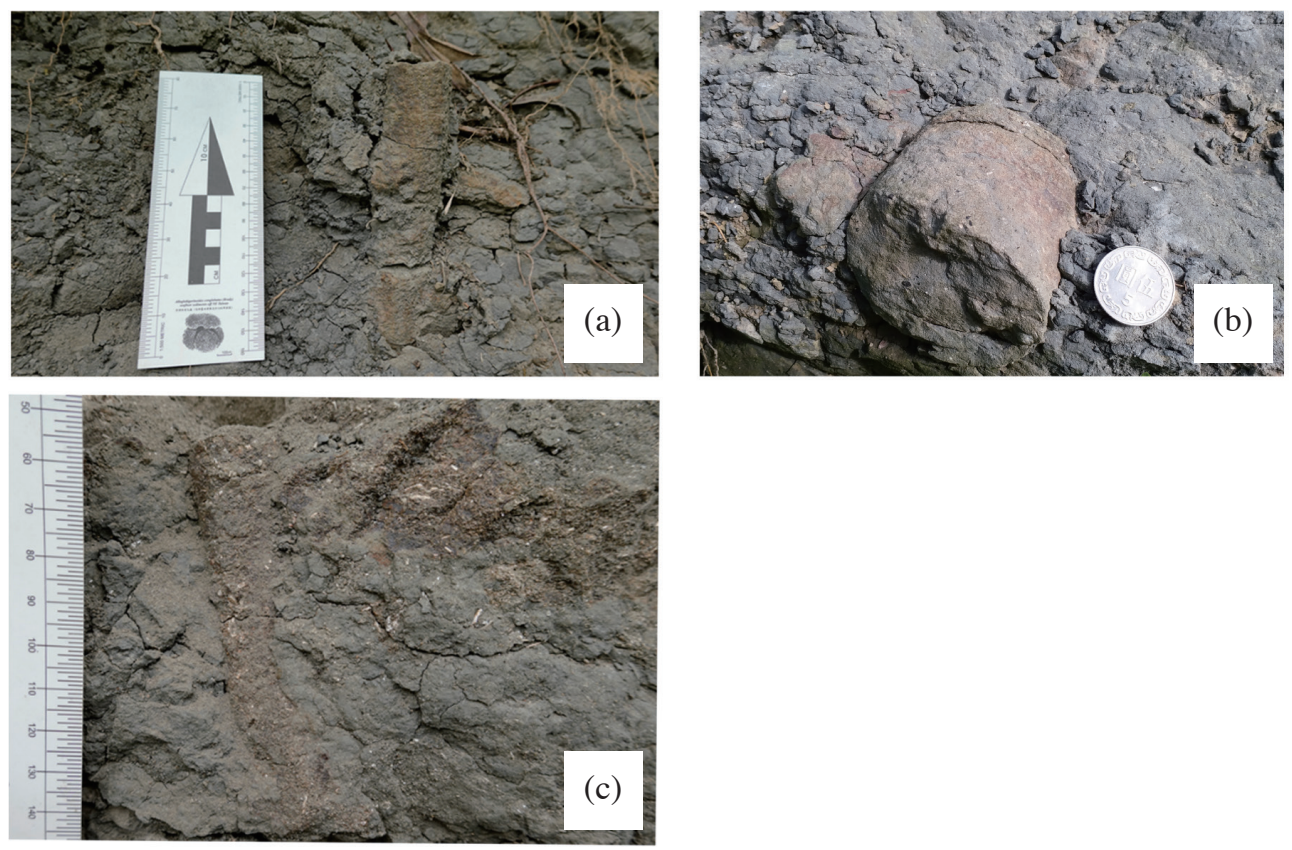

Fig. 9. Trace fossils observed in the outcrop.

are generally unable to extricate once they are buried and die; thus, they usually develop mass accumulations in areas where there is little sedimentation (Carmona et al. 2007; Hryniewicz and Gaździcki 2016). Although incomplete bivalve shells occur in the section throughout, there is at least one layer containing shells of " $P$. tzayi" with the preferred orientation perpendicular to bedding surface (Figs. 2c, d). Thus, specimens of " $P$. tzayi" were not redeposited nor were disturbed by other infaunal organisms based on the associated trace fossils (Fig. 9). In addition, there is no sign of escaping structures associated with body fossils of " $P$. tzayi". Therefore, the cause of death, leaving the preservation of bivalves in situ could be an obrution event with rapid burial due to a sudden increase in water depth and sedimentation rate (Shanmugam 2018; Jelby et al. 2020).

\subsection{Depositional Environments}

Based on previous studies (Yu and Teng 1995), the depositional settings of Chinshui Shale range from delta to barrier island transitional-offshore marine. Transitional to offshore settings are between fair weather wave base and storm wave base (roughly 5 - $15 \mathrm{~m}$ water depth), in where muddy sands accumulated with some bioturbation and rich shelly bioclasts and microfossils (Walker 1984; Walker and Plint 1992; Yu and Teng 1995) (Fig. 10).

\subsection{Boring Strategy and Implication for Field Geology}

Boring strategies of Pholadidae have been reported and reviewed recently (Nair and Ansell 1968; Kennedy
1974, 1993; Röder 1977; Carmona et al. 2006; Nederlof and Muller 2012). A few studies (e.g., Nair and Ansell 1968; Röder 1977; Hryniewicz and Gaździcki 2016) pointed out that there are two main types of boring strategies adapted by pholadoid bivalves depending on the substrate types.

Anterior boring is associated with species inhabiting rigid and semi-rigid substrates such as hardening resin of amber-producing trees (Smith and Ross 2016; Bolotov et al. 2021), wood, or rock (Nair and Ansell 1968; Kennedy 1974; Röder 1977; Hari et al. 2009; Monari 2009). On the other hand, ventral boring is associated with species inhabiting less rigid substrates, such as firmgrounds (Hryniewicz and Gaździcki 2016; and references therein). The absence of umbonal-ventral groove in studied specimens (Figs. 4 - 7) indicates the latter type for "Pholas tzayi".

Wang (1985) illustrated examples of using Taiwanese fossils and trace fossils for field geology. He used heart urchin beds of Schizaster sp. (Echinodermata: Schizasteridae) from Nangang Formation (Miocene) as an indicator for stratigraphic facing, orientations of gastropod Turritella sp. (Gastropoda: Turritellidae) from Wuchishan Formation (Oligocene) as paleocurrent indicators, and traces with escape structures from Erichiu Formation (Pliocene) for estimating the relative sedimentation rates. Here is the new example for stratigraphic facing indicator by using pholadid bivalves. Based on modern analogues, pholadids tend to burry themselves within the muddy firmgrounds (Cai et al. 1997) with their posterior ends (Carter et al. 2012) pointing upward, allowing siphon to reach the seawater. Based on the field observations, many specimens of " $P$. tzayi" were preserved in situ with their posterior ends pointing upward 


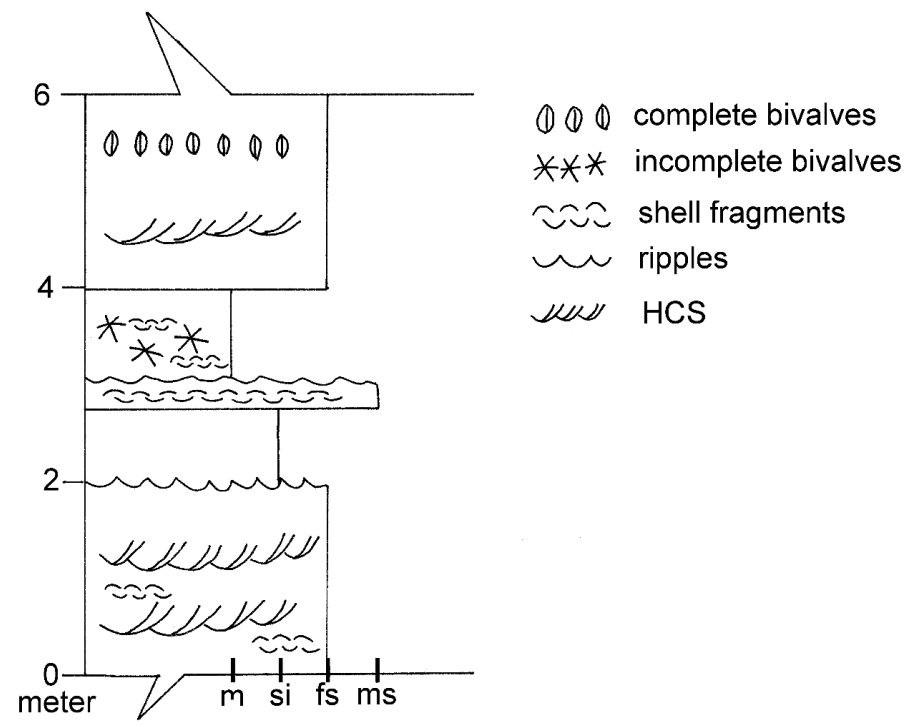

Fig. 10. Generalized column of Chinshui Shale in the studied area. $\mathrm{m}=$ Mud, $\mathrm{si}=\mathrm{Silt}$, $\mathrm{fs}=$ Fine sand, $\mathrm{ms}=$ Medium sand, HCS $=$ Hummocky Cross-Stratification.

(Figs. 2c, d), indicating that the stratigraphic up direction is toward the top. Due to intense bioturbation bedding is rare in the Chinshui Shale. "P. tzayi" layer provides independent clues about stratigraphic facing and seafloor conditions at the time of deposition.

\section{CONCLUSIONS}

Although "P. tzayi" has been reported in $\mathrm{Hu}$ (1992), this is the first documentation of the in situ preservation of pholadid bivalves in the field. Its preferred orientation, vertical to bedding (with posterior pointing upward), and completeness of intact shells allow us to understand seafloor conditions at the time of deposition.

" $P$. tzayi" adapted to tranquil muddy substrate and firmground below the fair weather wave base. It is absent in the overlying unit Chuolan Formation that deposited in shallower marine above the fair weather wave base and shoreface settings under the influence of orbital forcing (e.g., Vaucher et al. 2021).

"P. tzayi" occurs only in the upper Pliocene Chinshui Shale, close to the Plio-Pleistocene boundary. Thus, it is a key fossil, perhaps an index fossil, in the region. Due to the fact that "P. tzayi" was found buried in situ (Fig. 2c) an obrution event with rapid sedimentation is the most probable cause of death.

Acknowledgements Chen-Wen Shan, Ivan Bolotov, Krzysztof Hryniewicz, Wei-Chia Chu, and Li Lo commented on an earlier version of this manuscript. Hsiao-Jou Wu edited manuscript drafts. This study was supported by the Taiwan-ROC Ministry of Science and Technology grants (MOST 108-2116-M-002-014, MOST 109-2116-
M-002-020, and MOST 110-2116-M-002-016) awarded to Jih-Pai Lin.

\section{REFERENCES}

Bolotov, I. N., O. V. Aksenova, I. V. Vikhrev, E. S. Konopleva, Y. E. Chapurina, and A. V. Kondakov, 2021: A new fossil piddock (Bivalvia: Pholadidae) may indicate estuarine to freshwater environments near Cretaceous amber-producing forests in Myanmar. Sci.Rep., 11, 6646, doi: 10.1038/s41598-021-86241-y. [Link]

Cai, Y. Y., Y. Zhang, and R.F. Wei, 1997: Malacology, The Sueichan Press, 631 pp.

Carmona, N. B., J. J. Ponce, M. G. Mangano, and L. A. Buatois, 2006: Variabilidad de la icnofacies de Glossifungites en el contacto entre las Formaciones Sarmiento (Eoceno medio - Mioceno temprano) y Chenque (Mioceno temprano) en el Golfo San Jorge, Chubut, Argentina. Ameghiniana, 43, 413-425.

Carmona, N. B., M. G. Mángano, L. A. Buatois, and J. J. Ponce, 2007: Bivalve trace fossils in an early Miocene discontinuity surface in Patagonia, Argentina: Burrowing behavior and implications for ichnotaxonomy at the firmground-hardground divide. Palaeogeogr. Palaeoclimatol. Palaeoecol., 255, 329-341, doi: 10.1016/j. palaeo.2007.07.014. [Link]

Carter, J. G., P. J. Harries, N. Malchus, A. F. Sartori, L. C. Anderson, R. Bieler, A. E. Bogan, E. V. Coan, J. C. W. Cope, S. M. Cragg, J. R. García-March, J. Hylleberg, P. Kelley, K. Kleemann, J. Kř̌̌ž, C. McRoberts, P. M. Mikkelsen, J. Pojeta Jr., P. W. Skelton, I. Tëmkin, T. Yancey, and A. Zieritz, 2012: Illustrated glossary of the Bivalvia. Treatise Online, 1, 1-209. 
Chang, K. M. and C.-C. Lin, 1978: Description of a new subspecies of Pisidium taiwanensis from Tenchi, Taiwan (Bivalvia: Sphaeriidae). Bulletin of Malacology, 5, 23-27.

Chen, W. S., 1994: Trace fossils of Taiwan. Geology of Taiwan, 4, 1-101.

Chiu, T.-H., 2018: A Study on Paleoenvironments of the Late Pliocene to Early Pleistocene Foreland Basin in the Western Foothills of Central Taiwan. Master Thesis, Department of Earth Sciences, National Central University, Taoyuan City, Taiwan, 95 pp.

Chiu, W.-Y., 2009: Oligocene to Pleistocene basin development and sequence stratigraphy in northwest Taiwan. Master Thesis, Department of Earth Sciences, National Central University, Taoyuan City, Taiwan, 103 pp.

Cox, L. R., N. D. Newell, D. W. Boyd, C. C. Branson, R. Casey, A. Chavan, A. H. Coogan, C. Dechaseaux, C. A. Fleming, F. Haas, L. G. Hertlein, E. G. Kauffman, A. M. Keen, A. LaRocque, A. L. McAlester, R. C. Moore, C. P. Nuttall, B. F. Perkins, H. S. Puri, L. A. Smith, T. Soot-Ryen, H. B. Stenzel, E. R. Trueman, R. D. Turner, and J. Weir, 1969: Part N, Mollusca 6, vol. $1 \&$ 2. In: Moore, R. C. (Ed.), Treatise on Invertebrate Paleontology, Geological Society of America and University of Kansas Press, 702-740.

Deguchi, Y., 1912: Catalogue of fossils from Formosa. $J$. Geol. Soc. Jpn., 19, 419-428.

Hari, T., S. Bardhan, and D. Mukherjee, 2009: Sympatric character convergence between two species of closely related genera of Pholadinae (Bivalvia: Pholadidae) from the eastern coast of India. Malacologia, 51, 291306, doi: 10.4002/040.051.0205. [Link]

Hayasaka, I., 1931: A noteworthy occurrence of fossil shells in the gravel beds of terraces. Taiwan Tigaku Kizi, 2, 70-71.

Hayasaka, I., 1939: An outline of the history of paleontological research in Taiwan. Collected Papers In Memory of the 30th Anniversary of the Taiwan Governor-General Office Museum, 303-322.

Hayasaka, I. and C. C. Lin, 1934: Molluses from the shell mound of Nisi-Sinsyosi, Taihoku City. Taiwan Tigaku Kizi, 5, 79-82.

Hayasaka, I. and K. Tan, 1934a: An outline of the geology around the fossil shell localities near Hakushaton, Shinchiku Province. Taiwan Tigaku Kizi, 5, 37-42.

Hayasaka, I. and K. Tan, 1934b: Three mollusc species from Taiwan. Transactions of the Natural History Society of Taiwan, 24, 259-264.

Hayasaka, I. and K. Tan, 1935: The fossil shell bed of Hakushaton, Shinchiku Province. The Survey Report of Natural Monument in Interior Administration Bureau Department of Taiwan Governor-general's Office, 2, 19-29.

Hryniewicz, K. and A. Gaździcki, 2016: A new sediment- dwelling pholadid bivalve from Oligocene glaciomarine sediments of King George Island, West Antarctica. Acta Palaeontol. Pol., 61, 885-896, doi: 10.4202/ app.00255.2016. [Link]

Hryniewicz, K., S. Bakayeva, L. Heneralova, O. Hnylko, R. G. Jenkins, and A. Kaim, 2020: Taphonomy and palaeoecology of deep-water chemosymbiotic bivalves from the Eocene of Outer Eastern Carpathians, Ukraine. $P a$ laeogeogr. Palaeoclimatol. Palaeoecol., 553, 109782, doi: 10.1016/j.palaeo.2020.109782. [Link]

Hu, C. H., 1992: Mollusc fossils throughout Taiwan island. Taiwan Fossil Mollusk Fauna, National Museum of Natural Science, 1297-1375.

Hu, C. H., 1993: Tertiary molluscan fossils near Zhudong Town, Hsinchu County. Taiwan Fossil Mollusk Fauna, National Museum of Natural Science, 1723-1804.

Hu, C. H., 1995: Mollusc fossils throughout Taiwan island (part 2). Taiwan Fossil Mollusk Fauna, National Museum of Natural Science, 1927-2166.

Jelby, M. E., S.-A. Grundvåg, W. Helland-Hansen, S. Olaussen, and L. Stemmerik, 2020: Tempestite facies variability and storm-depositional processes across a wide ramp: Towards a polygenetic model for hummocky cross-stratification. Sedimentology, 67, 742781, doi: 10.1111/sed.12671. [Link]

Kaneko, S., 1943: Mollusks in Anping, Tainan and nearby regions. Transactions of the National History Society of Formosa, 33, 660-677.

Kanno, S., W. Hashimoto, C. C. Lin, N. Aoki, C. S. Lee, N. L. Caagusan, H. C. Liu, C. C. Wang, K. S. Shieh, and H. C. Chang, 1985: New Discovery of Colpospira (Acutospira), Gastropoda, from Taiwan and Philippine. Proc. Jpn. Acad. Ser. B-Phys. Biol. Sci., 61, 348-351, doi: 10.2183/pjab.61.348. [Link]

Kennedy, G. L., 1974: West American Cenozoic Pholadidae (Mollusca: Bivalvia), San Diego Society of Natural History, 127 pp.

Kennedy, G. L., 1993: New Cretaceous and Tertiary Pholadidae (Mollusca: Bivalvia) from California. $J$. Paleontol., 67, 397-404.

Kuroda, T., 1939: Notes on the shells from Taiwan (2). Venus, 9, 109-115.

Kuroda, T., 1940: Notes on the shells from Taiwan (3). Venus, 10, 97-107.

Lin, C.-C., 1974: Mollusks of Lanyu (Orchid Island) and their zoogeography. Bull. Chin Malacol. Soc., 1, 42-63.

Lin, C.-C., 1975: Miocene Pleurotomariidae from Nantou Prefecture, Central Taiwan. Bull. Chin Malacol. Soc., 2, 21-31.

Lin, C.-C., 1976: Discovery of a new pleurotomariid from Taipei Prefecture, Taiwan. Bull. Chin Malacol. Soc., 3, 13-19.

Lin, C.-C. and P. M. Liew, 1978: Paleontology. In: Lin, 
C.-C. and J.-T. Chou (Eds.), Geology of Taiwan, Maochang Book, Ltd., Taipei, Taiwan, 227-449.

Masuda, K., 1990: Present state of molluscan paleontology in Taiwan. Fossils, 49, 33-34.

Masuda, K. and C.-Y. Huang, 1994: Pliocene shallow marine mollusks of the Chinsui and Choulan Formations in the Miaoli area, northern Taiwan. J. Geol. Soc. China, 37, 385-405.

Monari, S., 2009: Phylogeny and biogeography of pholadid bivalve Barnea (Anchomasa) with considerations on the phylogeny of Pholadoidea. Acta Palaeontol. Pol., 54, 315-335, doi: 10.4202/app.2008.0068. [Link]

Nair, N. B. and A. D. Ansell, 1968: The mechanism of boring in Zirphaea crispata (L.) (Bivalvia: Pholadidae). Proc. R. Soc. Lond. Ser. B-Biol. Sci., 170, 155-173, doi: 10.1098/rspb.1968.0031. [Link]

Nederlof, R. and M. Muller, 2012: A biomechanical model of rock drilling in the piddock Barnea candida (Bivalvia; Mollusca). J. R. Soc. Interface, 9, 2947-2958, doi: 10.1098/rsif.2012.0329. [Link]

Nomura, S., 1933: Catalogue of the Tertiary and Quartery Mollusca from the island of Taiwan (Formosa) in the Institute of Geology and Palaeontology. Sendai, Japan, Part 1: Pelecypoda. Sci. Rept. Tohoku Imp. Univ., 16, 1-108.

Nomura, S., 1935: Catalogue of the Tertiary and Quartery Mollusca from the island of Taiwan (Formosa) in the Institute of Geology and Palaeontology, Sendai, Japan, Part 2: Scaphopoda and Gastropoda. Sci.Rept. Tohoku Imp. Univ., 18, 53-228.

Nomura, S., 1938: Pyramidellid molluscs from the Byoritu Beds of Taiwan. J. Geol. Soc. Jpn., 45, 821-832, doi: 10.5575/geosoc.45.821. [Link]

Otuka, Y., 1936: Notes on some shells from southern Taiwan (1). Venus, 6, 155-162.

Pan, K.-C., 2015: Sedimentary environment and evolution of Kueichulin Formation and Chinshui Shale in Miaoli, northwestern Taiwan. Master Thesis, Department of Earth Sciences, National Cheng Kung University, Taiwan, $115 \mathrm{pp}$.

Pan, T.-Y., 2011: A study on sedimentary environments of Nanchuang Formation to Yangmei Formation along the Dahan River section, northwestern Taiwan. Master Thesis, Department of Earth Sciences, National Central University, Taoyuan City, Taiwan, 99 pp.

Röder, H., 1977: Zur Beziehung zwischen Konstruktion und Substrat bein mechanisch bohrenden Bohrmuscheln (Pholadidae, Teredinidae). Senchenbergiana Maritima, 9, 105-214.

Shanmugam, G., 2018: The hyperpycnite problem. J.Palaegeogr., 7, 6, doi: 10.1186/s42501-018-0001-7. [Link]

Smith, R. D. A. and A. J. Ross, 2016: Amberground pholadid bivalve borings and inclusions in Burmese amber: Implications for proximity of resin-producing forests to brackish waters, and the age of the amber. Earth and Environmental Science Transactions of the Royal Society of Edinburgh, 107, 239-247, doi: 10.1017/S1755691017000287. [Link]

Tan, K., 1932: On the fossil Mollusca ejected from the mudvolcanoes near Kyoshito, Takao Prefecture, Taiwan. Taiwan Tigaku Kizi, 3, 34-37.

Tan, K., 1933: On the variation of recent and prehistoric specimens of Corbicula Maxima Prime. Venus, 4, 289-302.

Tan, K., 1937: Fossil shells found at the site of the harbor construction of Karenko (misc. notes on Taiwan fossils, 6). Taiwan Tigaku Kizi, 8, 62-70.

Vaucher, R., S. E. Dashtgard, C.-S. Horng, C. Zeeden, A. Dillinger, Y.-Y. Pan, R. A. Setiaji, W.-R. Chi, and L. Löwemark, 2021: Insolation-paced sea level and sediment flux during the early Pleistocene in Southeast Asia. Sci. Rep., 11, 16707, doi: 10.1038/s41598-02196372-x. [Link]

Walker, R. G., 1984: Facies Models, 2 Edition, Geological Association of Canada, Business and Economic Service, $317 \mathrm{pp}$.

Walker, R. G. and A. G. Plint, 1992: Wave- and stormdominated shallow marine systems. In: Walker, R. G. and N. P. James (Eds.), Facies Models: Response to Sea Level Change, Geological Association of Canada, GeoText 1, Newfoundland, 219-238.

Wang, C.-C., 1983: On a new subgenus and new species of the pholadid bivalves from the Miocene of Taiwan. Bulletin of the Central Geological Survey, 2, 121-129.

Wang, C.-C., 1984: Cenozoic bivalves Pholadomya from Taiwan. Bulletin of the Central Geological Survey, 3, 73-79.

Wang, C. C., 1985: Application of fossils in field geology: Some examples. Annual Report of Central Geological Survey, 1985, 57-60.

Yeh, J.-J., 2017: Petrographic study of the Miocene-Pleistocene sandstone in the Western Foothills, northern Taiwan: Implication for the unroofing history of Taiwan orogenic belt. Master Thesis, Department of Geosciences, National Taiwan University, Taipei City, Taiwan, 104 pp, doi: 10.6342/NTU201703422. [Link]

Yokoyama, M., 1920: Fossils from the Miura Peninsula and its Immediate North. The journal of the College of Science, Tokyo Imperial University, 39, 1-193.

Yokoyama, M., 1928: Mollusca from the oil fields of the island of Taiwan. Imp. Geol. Surv. Japan. Rept., 101, $1-31$.

Yu, N.-T. and L. S. Teng, 1995: The lithofacies and sedimentary environments of the Miocene outcrops of the Chuhuangkeng section, northwestern Taiwan. Ti-Chih, 15, 127-152. 